\title{
Ceramide galactosyltransferase (UGT8) is a molecular marker of breast cancer malignancy and lung metastases
}

\section{P Dzięgiel 1,6,7, T Owczarek ${ }^{2}$, E Plażuk ${ }^{3}$, A Gomułkiewicz', M Majchrzak ${ }^{4}$, M Podhorska-Okołów', K Driouch ${ }^{5}$, R Lidereau ${ }^{5}$ and $M$ Ugorski $^{*, 2,3}$}

'Department of Histology and Embryology, Medical University, T. Chałubińskiego 6a, Wrocław 50-368, Poland; ${ }^{2}$ Department of Biochemistry, Pharmacology and Toxicology, Faculty of Veterinary Medicine, University of Environmental and Life Sciences, C. Norwida 31, Wrocław 50-357, Poland; ${ }^{3}$ Laboratory of Glycobiology and Cell Interactions, Ludwik Hirszfeld Institute of Immunology and Experimental Therapy, Polish Academy of Sciences,

R. Weigla 12, Wrocław 53- I 4, Poland; ${ }^{4}$ Department of Thoracic Surgery, Medical University, Grabiszyńska 105, Wrocław 53-430, Poland;

${ }^{5}$ Oncogenetics laboratory/INSERM U 735, Saint-Cloud, France; ${ }^{6}$ Department of Histology and Embryology, Medical University, Święcickiego 6,

Poznań 61-78I, Poland; ${ }^{7}$ Department of Pathology, Lower Silesian Oncology Center, Wrocław 53-4I3, PI. Hirszfelda 12, Poland

BACKGROUND: It was shown recently on the level of gene expression that UGT8, coding UDP-galactose:ceramide galactosyltransferase, is one of six genes whose elevated expression correlated with a significantly increased the risk of lung metastases in breast cancer patients. In this study primary tumours and their lung metastases as well as breast cancer cell lines were analysed for UGT8 expression at the protein level.

METHODS: Expression of UGT8 in breast cancer tissue specimens and breast cancer cell lines was analysed using $I H C$, real-time PCR and Western blotting.

RESULTS: Comparison of the average values of the reaction intensities (IRS scale) showed a significant difference in UGT8 expression between (I) primary and metastatic tumours (Mann-Whitney $U, P<0.05$ ), (2) tumours of malignancy grades G3 and G2 (Mann-Whitney $U, P<0.0 I$ ) as well as $G 3$ and $G I$ (Mann-Whitney $U, P<0.00 I$ ) and (3) node-positive and node-negative tumours (Mann-Whitney $U, P<0.00 I$ ). The predictive ability of increased expression of UGT8 was validated at the mRNA level in three independent cohorts of breast cancer patients (72I). Similarly, breast cancer cell lines with the 'luminal epithelial-like' phenotype did not express or weakly expressed UGT8, in contrast to malignant, 'mesenchymal-like,' cells forming metastases in nude mice. CONCLUSION: Our data suggest that UGT8 is a significant index of tumour aggressiveness and a potential marker for the prognostic evaluation of lung metastases in breast cancer.

British Journal of Cancer (2010) I 03, 524-53I. doi:I0.1038/sj.bjc.6605750 www.bjcancer.com

Published online 20 July 2010

(c) 2010 Cancer Research UK

Keywords: breast cancer; metastasis; UGT8; molecular marker; GalCer

The endoplasmic reticulum-localised enzyme UDP-galactose:ceramide galactosyltransferase (UGT8, CGT, C. E. 2.4.2.62) (Schulte and Stoffel, 1993; Kapitonov and Yu, 1997; Sprong et al, 1998) is responsible for the synthesis of galactosylceramide (GalCer), which is the major glycosphingolipid of myelin produced by oligodendrocytes in the central nervous system (CNS) and Schwann cells in the peripheral nervous system (Marcus and Popko, 2002). The exact role of GalCer in myelin sheath development and function is poorly understood; however this glycolipid is well recognised as a specific marker for the differentiation of these cells (Pfeiffer et al, 1993). Studies using antibodies suggested that GalCer may participate in signal transduction by regulating the intracellular calcium level and in this way mediating cytoskeletal rearrangements (Dyer and Benjamins, 1990, 1991). On the basis of a knockout mice model lacking UGT8, it was proposed that GalCer, together with sulphatide, is involved in myelin function and stability but not in its biogenesis (Bosio et al, 1996; Coetzee et al,

*Correspondence: Dr M Ugorski; E-mail: ugorski@immuno.iitd.pan.wroc.pl Received 5 March 2010; revised I8 May 20 I0; accepted 27 May 20 I0; published online 20 July 2010
1996; Dupree et al, 1999). In addition to myelin, GalCer was also found in normal kidney (Ariga et al, 1980; Kodama et al, 1982), small intestine and colon (Natomi et al, 1993), liver (Nilsson and Svennerholm, 1982), testis (Vos et al, 1994), and milk (Bouhours and Bouhours, 1979).

Since the pioneering work of Hakomori and Murakami (1968), it was firmly established that neoplastic transformation and tumour progression are almost invariably associated with changes in the expression profiles of surface glycosphingolipids (Hakomori, 1996). However, there is very little information available on GalCer expression in human tumours. Only in studies on molecular markers in human astrocytomas and oligodendrogliomas was it found that high amounts of GalCer were present more frequently in oligodendrogliomas than in astrocytomas (Sung et al, 1996; Popko et al, 2002). Interestingly, more is known about the expression of UGT8 in cancerous tissues. Transcriptome profiling of prostate cancer cell lines showed that cells with metastatic properties express a much higher level of UGT8 mRNA in comparison with non-metastatic cells (Oudes et al, 2005). Using the same approach, we recently showed that UGT8 is one of six genes whose elevated expression correlated with a significantly 
increased risk of lung metastases in breast cancer patients (Landemaine et al, 2008). It was also found that elevated expression of UGT8 in breast cancer was significantly associated with ER-negativity, and therefore with a more malignant phenotype (Yang et al, 2006; Ruckhäberle et al, 2008).

As all the available information on the presence of UGT8 in breast cancer tissues was obtained only at the level of mRNA expression, primary tumours of different malignancy grades and their lung metastases were analysed for UGT8 expression at the protein level. In addition, presence of UGT8 and GalCer was determined in breast cancer cell lines representing different tumour phenotypes.

\section{MATERIALS AND METHODS}

\section{Tissue specimens and cell lines}

Tissue blocks from 10 patients with primary breast cancer (invasive ductal carcinoma, IDC) were obtained from the Department of Pathology, Lower Silesian Center of Oncology (Wrocław, Poland) (eight cases) and Department of Pathology, Centre René Huguenin (Saint-Cloud, France) (two cases). Their corresponding lung metastases were collected also as tissue blocks from the Department of Thoracic Surgery, Wrocław Medical University (Poland), and Department of Pathology, Centre René Huguenin (Saint-Cloud, France) (Table 1). Thirty tissue specimens were obtained from patients who underwent resections of primary IDC at the Lower Silesian Center of Oncology, Wrocław (Poland) (Table 1). For mRNA analysis they were frozen at $-80^{\circ} \mathrm{C}$ and for immunohistochemical staining they were fixed in $10 \%$ neutralbuffered formalin and embedded in paraffin. Paraffin sections, mounted on Superfrost Plus slides (Menzel Glaser, Braunschweig, Germany), were dehydrated and stained with haematoxylin and

Table 1 Patients and tumour characteristics

\begin{tabular}{|c|c|c|c|c|}
\hline & \multicolumn{2}{|c|}{$\begin{array}{l}\text { Tumours without } \\
\text { lung metastases }\end{array}$} & \multicolumn{2}{|c|}{$\begin{array}{l}\text { Tumours with } \\
\text { lung metastases }\end{array}$} \\
\hline Mean age in years (range) & $58.4(32$ & 80) & $59.8(43$ & 7I) \\
\hline $\begin{array}{l}\text { Parameters } \\
\text { Invasive ductal carcinoma (IDC) }\end{array}$ & $\underset{30}{\text { Number }}$ & $\begin{array}{c}\% \\
100.0\end{array}$ & $\underset{10}{\text { Number }}$ & $\begin{array}{c}\% \\
100.0\end{array}$ \\
\hline Size & & & & \\
\hline $\begin{array}{l}\text { TI }(<2 \mathrm{~cm}) \\
\text { T2 }(2-5 \mathrm{~cm}) \\
\text { T3 }(>5 \mathrm{~cm})\end{array}$ & $\begin{array}{r}16 \\
11 \\
3\end{array}$ & $\begin{array}{l}53.3 \\
36.7 \\
10.0\end{array}$ & $\begin{array}{l}3 \\
4 \\
3\end{array}$ & $\begin{array}{l}30.0 \\
40.0 \\
30.0\end{array}$ \\
\hline $\begin{array}{l}\text { Lymph nodes } \\
\text { Negative } \\
\text { Positive }\end{array}$ & $\begin{array}{r}22 \\
8\end{array}$ & $\begin{array}{l}73.3 \\
26.7\end{array}$ & 10 & 100.0 \\
\hline $\begin{array}{r}\text { Grade } \\
\text { G1 } \\
\text { G2 } \\
\text { G3 }\end{array}$ & $\begin{array}{r}8 \\
7 \\
15\end{array}$ & $\begin{array}{l}26.7 \\
23.3 \\
50.0\end{array}$ & $\begin{array}{l}1 \\
3 \\
6\end{array}$ & $\begin{array}{l}10.0 \\
30.0 \\
60.0\end{array}$ \\
\hline $\begin{array}{l}\text { ER } \\
\text { Positive } \\
\text { Negative }\end{array}$ & $\begin{array}{l}20 \\
10\end{array}$ & $\begin{array}{l}66.7 \\
33.3\end{array}$ & $\begin{array}{l}4 \\
6\end{array}$ & $\begin{array}{l}40.0 \\
60.0\end{array}$ \\
\hline $\begin{array}{l}\text { PR } \\
\text { Positive } \\
\text { Negative }\end{array}$ & $\begin{array}{l}13 \\
17\end{array}$ & $\begin{array}{l}43.3 \\
56.7\end{array}$ & $\begin{array}{l}7 \\
3\end{array}$ & $\begin{array}{l}70.0 \\
30.0\end{array}$ \\
\hline $\begin{array}{c}\text { HER2 by IHC } \\
\text { Positive } \\
\text { Negative }\end{array}$ & $\begin{array}{r}6 \\
24\end{array}$ & $\begin{array}{l}20.0 \\
80.0\end{array}$ & $\begin{array}{l}2 \\
8\end{array}$ & $\begin{array}{l}20.0 \\
80.0\end{array}$ \\
\hline
\end{tabular}

eosin. Malignant tumours were graded according to the classification of Bloom-Richardson with the modification of Elston and Ellis (1991). The study was approved by the Bioethical Committee of the Wrocław Medical University (no. KB-87/2005).

Three breast tumour series, the 'MSK', 'EMS', and 'NKI' cohorts (van de Vijver et al, 2002; Wang et al, 2005; Minn et al, 2005a,b, 2007), for which microarray data are freely available, were also included in this study.

The following breast cancer cell lines were used in this study: MCF7, T47D, SKBR-3, BT-474, MDA-MB-231 (Cell Lines Collection of the Ludwik Hirszfeld Institute of Immunology and Experimental Therapy, Wrocław, Poland), MCF10CA1a.cl1 (provided by Dr S Santner, Karmanos Cancer Institute, Detroit, USA) and $\mathrm{BO} 2$ as a derivative of the MDA MB 231 cell line (provided by Dr Philippe Clezardin, INSERM U664, France). The cells were cultured in $\alpha$-minimum essential medium ( $\alpha \mathrm{MEM})$ supplemented with $10 \%$ foetal calf serum (FCS; Invitrogen, Carlsbad, CA, USA), $2 \mathrm{~mm}$ L-glutamine, and antibiotics.

\section{Immunohistochemistry}

For immunohistochemical staining, 4- $\mu$ m-thick paraffin sections were deparaffinised in xylene and gradually rehydrated using ethanol. Endogenous peroxidase activity was blocked by a 5 -min exposure to $3 \% \mathrm{H}_{2} \mathrm{O}_{2}$. The cultured cells in eight-well culture slides (Becton Dickinson, Franklin Lakes, NJ, USA) were fixed in $4 \%$ neutral-buffered formalin for $15 \mathrm{~min}$. Antigen retrieval was performed by exposure of the tissue sections and breast cancer cell lines to boiling Antigen Retrieval Solution (Dako, Glostrup, Denmark) in a microwave oven $(250 \mathrm{~W})$ for $15 \mathrm{~min}$. Rabbit polyclonal antibodies directed against UGT8 were purchased from Atlas Prestige Antibodies (Stockholm, Sweden). The antibodies were diluted with Background Reducing Antibody Diluent (Dako). The sections were incubated with primary antibodies for $1 \mathrm{~h}$ at room temperature. Goat secondary antibodies (EnVision/HRP; Dako) directed against rabbit immunoglobulins were bound to a dextran framework conjugated with peroxidase. The reaction was developed using 3,3'-diaminobenzidine tetrachloride (DAB). Primary Negative Control (Dako) was used as the negative control. All tissue sections were counterstained with Mayer's haematoxylin.

The obtained photomicrographs were subjected to computerassisted image analysis using a computer coupled to an Olympus BX-41 light microscope (Olympus, Tokyo, Japan) using the AnalySis software (Olympus). The degree of UGT8 expression was ranked using the modified semi-quantitative Immunoreactive Remmele Score (IRS) according to Remmele and Stegner (1987). The method takes into account both the proportion of stained cells and the intensity of the reaction, while its final results represent the product of the two parameters, with values ranging from 0 to 12 points (no reaction $=0$ points, weak reaction $=1-2$ points, moderate reaction $=3-4$ points, intense reaction $=6-12$ points). The results were subjected to statistical analysis using the Statisitica 7.1 software (StatSoft, Kraków, Poland). When groups of data were compared, which failed to satisfy assumptions of the parametric test, the Mann-Whitney $U$-test, the non-parametric equivalent of Student's $t$-test, was used. For matched samples of primary tumours and their metastases, the Wilcoxon signed rank sum test, the non-parametric version of a paired-samples $t$-test, was used. Correlations were tested by Spearman's correlation analysis. Results were considered statistically significant with $P<0.05$ in all analyses. Survivals times were determined by the Kaplan-Meier method and significance of differences were determined by log-rank test.

\section{RT-PCR and real-time PCR}

Total RNA was isolated from the tissue samples using the RNeasy Fibrous Tissue Mini Kit (Qiagen, Hilden, Germany) according to 
Table 2 Oligonucleotide primers used in real-time PCR experiments

\begin{tabular}{|c|c|c|c|c|}
\hline $\begin{array}{l}\text { Target } \\
\text { sequence }\end{array}$ & Name & $\begin{array}{l}\text { Primer } \\
\text { location } \\
\text { in human } \\
\text { cDNA }\end{array}$ & $\begin{array}{l}\text { Nucleotide sequence } \\
\text { of primers }\left(5^{\prime} \rightarrow 3^{\prime}\right)\end{array}$ & $\begin{array}{l}\text { Product } \\
\text { size (bp) }\end{array}$ \\
\hline UGT8 & $\begin{array}{l}\text { RealUGT8f } \\
\text { RealUGT8r }\end{array}$ & $\begin{aligned} 834 & \rightarrow 854 \\
1145 & \leftarrow 1167\end{aligned}$ & $\begin{array}{l}\text { ATGGGTAAATGGTGCTAATG } \\
\text { TCTGGTCATAGTATCATAATGG }\end{array}$ & 334 \\
\hline GAPDH & $\begin{array}{l}\text { SGAPDH } \\
\text { ASGAPDH }\end{array}$ & $\begin{array}{l}536 \rightarrow 553 \\
916 \leftarrow 935\end{array}$ & $\begin{array}{l}\text { TCACTGCCACCCAGAAGA } \\
\text { TACCAGGAAATGAGCTTGAC }\end{array}$ & 399 \\
\hline
\end{tabular}

the manufacturer's instructions. The protocol included on-column DNAse digestion to remove the genomic DNA. First-strand cDNA was synthesised using the SuperScript III First-Strand Synthesis System (Invitrogen, Carlsbad, CA, USA). The relative amounts of UGT8 mRNA were determined by quantitative real-time PCR with an iQ5 Optical System and iQ SYBR Green Supermix (Bio-Rad, Hercules, CA, USA) according to the manufacturer's protocols. GAPDH was used as a reference gene. The primers used were: realUGT8f/realUGT8r for UGT8 and SGAPDH/ASGAPDH for GAPDH (Table 2). The reactions were performed under the following conditions: initial denaturation at $94^{\circ} \mathrm{C}$ for $120 \mathrm{~s}$, followed by 35 cycles of denaturation at $94^{\circ} \mathrm{C}$ for $30 \mathrm{~s}$, annealing at $58^{\circ} \mathrm{C}$ for $30 \mathrm{~s}$, and elongation at $72^{\circ} \mathrm{C}$ for $60 \mathrm{~s}$. The specificity of the PCR was determined by melt-curve analysis for each reaction.

\section{SDS-PAGE and Western blotting}

Cell lysates were obtained by treating the cells with RIPA lysis buffer (50 mm Tris- $\mathrm{HCl}, \mathrm{pH} 8.0,150 \mathrm{~mm} \mathrm{NaCl}, 0.1 \%$ SDS, 1\% IGEPAL Ca$630,0.5 \%$ sodium deoxycholate). Proteins were quantified using a bicinchonic acid protein assay kit (Sigma-Aldrich, St Louis, MO, USA) and subjected to electrophoresis on $8 \%$ SDS-PAGE gel according to Laemmli. After electrophoresis, the proteins were transferred to a nitrocellulose membrane (Bio-Rad). UGT8 was detected with rabbit polyclonal antibodies (Atlas Antibodies, Stockholm, Sweden) and horseradish peroxidase-conjugated donkey anti-rabbit immunoglobulins (Jackson ImmunoResearch, West Grove, PA, USA). The bound antibodies were visualised with the Lumi-Light ${ }^{\text {PLUS }}$ Luminal/Enhancer Solution and Lumi-Light ${ }^{\text {PLUS }}$ Stable Peroxidase Solution (Roche, Basel, Switzerland). The light-sensitive membrane was then developed by incubating with the Kodak Developer and Kodak Fixer according to the kit's protocol (Kodak, Rochester, NY, USA).

\section{Purification of neutral glycolipids and thin-layer chromatogram binding assay}

Neutral glycolipids were purified as described previously (Ugorski et al, 1989). Cell pellets corresponding to $10^{8}-10^{9}$ cells were extracted with chloroform/methanol/water, 20/10/1, 10/20/1, and $10 / 10 / 1$ by volume. Combined extracts were subjected to mild alkaline hydrolysis with $0.2 \mathrm{M} \mathrm{KOH}$ in methanol and desalted on a column of Sephadex G-25 superfine (Pharmacia Biotech, Uppsala, Sweden). The gangliosides were separated from the neutral glycolipids on a DEAE-Sephadex A-25 column (Pharmacia Biotech). The neutral glycolipids were further purified after acetylation on a Florisil column (Merck, Darmstadt, Germany) and analysed by high-performance thin-layer chromatography (HP-TLC) on silica gel $60 \mathrm{HP}$-TLC plates (Merck) with a solvent system of 2-propanol/15 M ammonia solution/methyl acetate/ water, $75 / 10 / 5 / 15$ by volume. (Ogawa et al, 1988). The standard for GalCer was obtained from Sigma-Aldrich. GalCer was detected by a TLC binding assay with rabbit polyclonal antibodies directed against GalCer (Sigma-Aldrich) and AffiniPure goat anti-rabbit IgG (Jackson ImmunoResearch) (Magnani et al, 1982). The latter

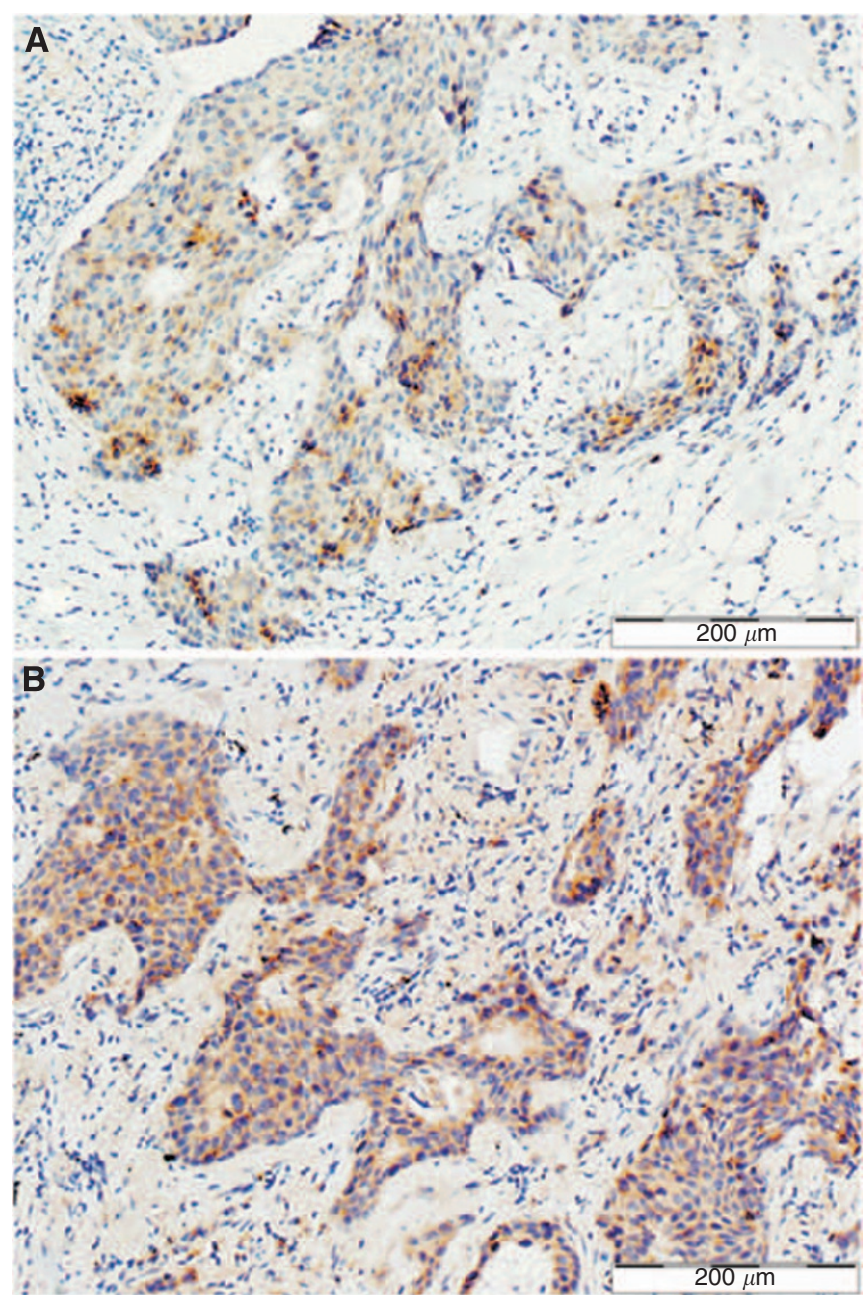

Figure I Immunohistochemical staining of primary breast carcinoma $(\mathbf{A})$ and paired lung metastasis (B) with anti-UGT8 rabbit polyclonal antibodies.

were labelled with $\mathrm{K}^{125} \mathrm{I}$ (PerkinElmer, Waltham, MA, USA) using Iodo-Beads Iodination Reagent (Pierce, Rockford, IL, USA) according to the manufacturer's instructions.

\section{RESULTS}

\section{Expression of UGT8 in primary breast cancer tumours and their metastases to the lung}

On the basis of histological examination 10 primary breast carcinomas and their matched metastases were included in this study. The primary carcinomas were classified according to the Bloom-Richardson scale in the modification of Elston and Ellis (1991) as G1 (1 case), G2 (3 cases), and G3 (6 cases). Expression of UGT8 in the paraffin sections of the cancer tissue specimens was analysed using rabbit polyclonal antibodies. All primary tumours except one stained more weakly with anti-UGT8 antibodies than did the lung metastases (Figure 1). Comparison of the average values of the reaction intensities (IRS scale) showed a significant difference (Wilcoxon $t$-test, $P<0.017$ ) in UGT 8 expression between primary and metastatic tumours (Table 3 ). Using IHC, UGT8 expression was also studied in the primary tumours according to their malignancy grades. For staining with anti-UGT8 antibodies, additional paraffin sections from 8 tumours of grade G1, seven tumours of grade G2, and 15 tumours of grade G3 were included. 
Table 3 Immunohistochemical expression of UGT8 in primary breast carcinomas and paired lung carcinomas ${ }^{a}$

\begin{tabular}{lcc}
\hline & \multicolumn{2}{c}{ IRS scale $^{\mathbf{a}}$} \\
\cline { 2 - 3 } Number & Primary tumour & Lung metastasis \\
\hline 1 & 2 & 4 \\
2 & 3 & 2 \\
3 & 1 & 3 \\
4 & 2 & 3 \\
5 & 1 & 1 \\
6 & 1 & 2 \\
7 & 2 & 4 \\
8 & 2 & 4 \\
9 & 2 & 3 \\
10 & 2 & 4 \\
Mean & 1.8 & 3.0 \\
S.d. & 0.63 & 1.05 \\
$P$ & 0.017 & \\
\hline
\end{tabular}

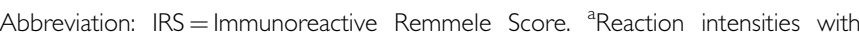
rabbit polyclonal antibodies for UGT8 were calculated on the basis of the semi-quantitative IRS scale of Remmele and Stegner (1987) and are represented as means. $P<0.017$ for UGT8-expressing primary breast tumours as compared with that for matched lung metastases (Wilcoxon signed rank sum test).

It was found that the expression of UGT8 in the tumour cells increased with increasing malignancy grade, reaching the highest values in the weakly differentiated cells (G3) (Figure 2A-C). When the average values of the reaction intensities (IRS scale) for tumours of different histological differentiation were compared by the Mann-Whitney $U$-test significant differences in UGT8 expression between malignancy grades $\mathrm{G} 3$ and $\mathrm{G} 2(P<0.01)$ as well as G3 and G1 $(P<0.001)$ were found (Figure $2 \mathrm{D})$. The results obtained at the protein level were confirmed when 30 primary tumours available as tissue specimens were also analysed by realtime PCR (Figure 3A). A significant positive correlation $(r=0.58$, $P<0.05)$ between the expression of UGT8 protein and UGT8 mRNA was found using Spearman's correlation analysis (Figure 3B). The intensity of UGT8 staining in node-positive breast cancer tumours, according to the IRS scale, amounted on average to $4.7 \pm 1.53$ and in node-negative tumours to $2.41 \pm 1.24$ This difference also proved to be significant $(P<0.001)$ (Figure 4$)$.

To validate the predictive ability of the elevated expression of UGT8 in primary breast tumours, the level of mRNA for UGT8 was analysed in three independent cohorts of breast cancer patients whose microarray data were available (van de Vijver et al, 2002; Wang et al, 2005; Minn et al, 2005a, b, 2007) (Figure 5). In all three analysed cohorts, patients assigned to the high-risk group had significantly shorter lung metastasis-free survival.

\section{Expression of UGT8 in established breast cancer cell lines}

The following breast cancer cell lines were used to analyse the expression of UGT8 with rabbit polyclonal antibodies: MCF-7,

Figure 2 Immunohistochemical staining of primary breast carcinomas representing different malignancy grades $(G I-G 3)$. UGT8 expression in primary breast carcinomas of different malignancy grades: $(\mathbf{A}) \mathrm{GI}(n=9)$, (B) $G 2(n=10)$, and (C) $G 3(n=21)$. Reaction intensities with rabbit polyclonal antibodies for UGT8 (D) were calculated on the basis of the semi-quantitative IRS scale of Remmele and Stegner (1987) and are represented as means; $* P<0.0$ I for primary breast tumours of grade $G 3$ as compared with primary breast tumour of grade G2, and ${ }^{\#} P<0.00$ I for primary breast tumours of grade $\mathrm{G} 3$ as compared with primary breast tumours of grade GI (Mann-Whitney U-test)
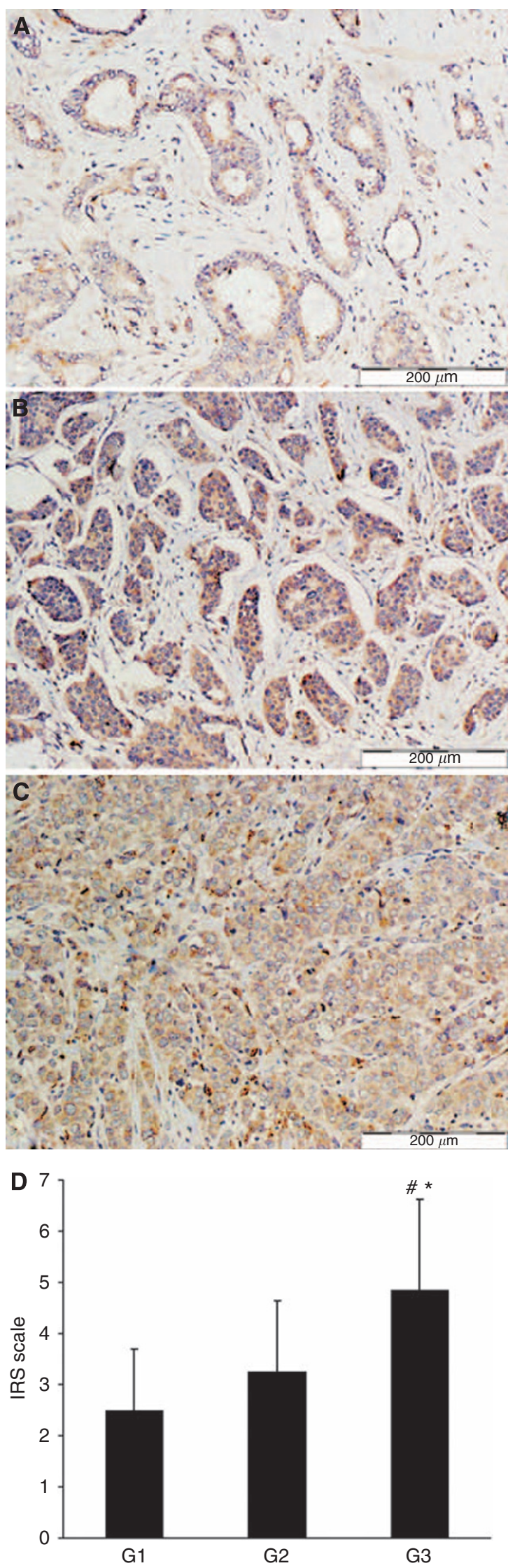

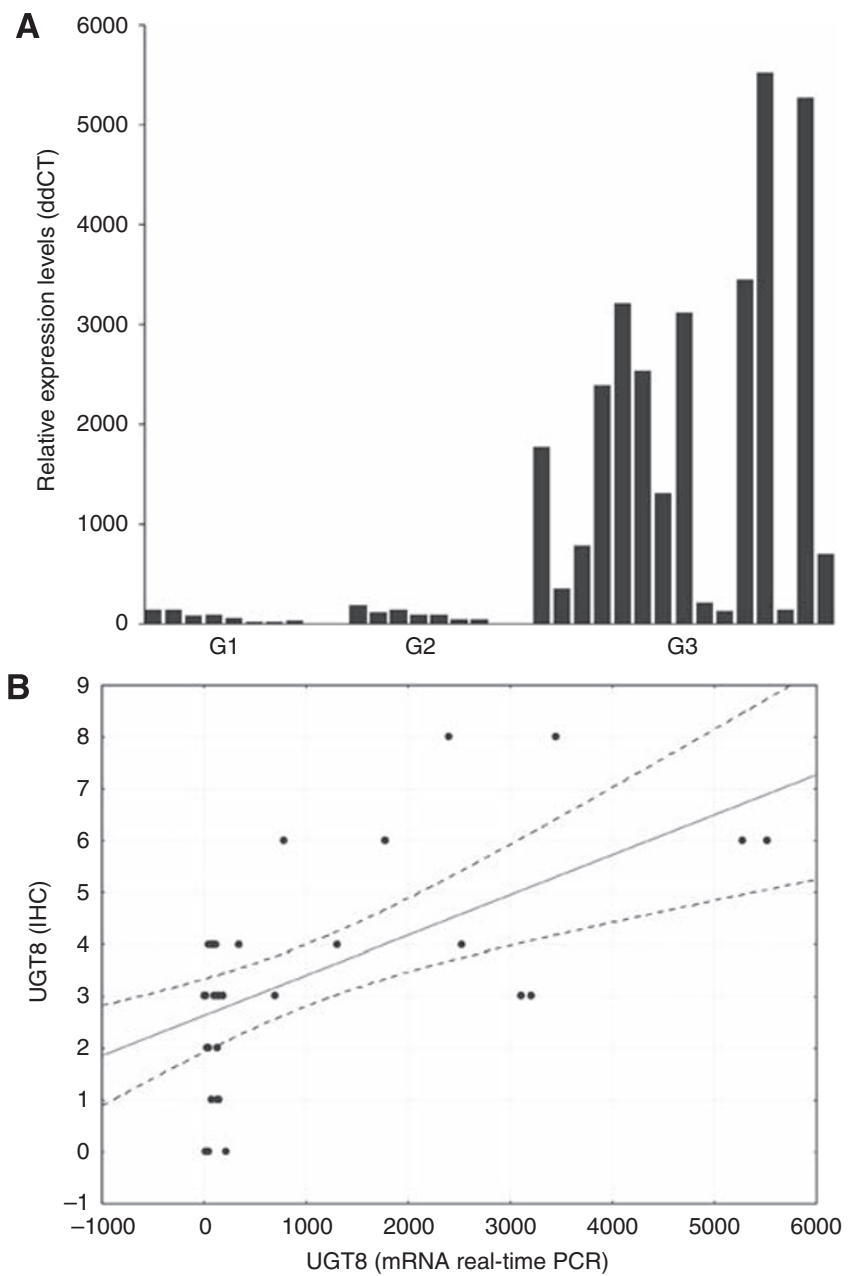

Figure 3 (A) Expression of UGT8 mRNA in primary breast tumours of different malignancy grades. Real-time RT-PCR was used to analyse UGT8 mRNA. UGT8 levels were normalised against GAPDH and cell line MCF-7 was assigned as a calibrator sample. (B) Positive correlation between intensity of UGT8 expression (immunohistochemistry, IHC) and UGT8 mRNA level (real-time PCR) in invasive ductal carcinoma. $r=0.58, P<0.05$ (Spearman's correlation).

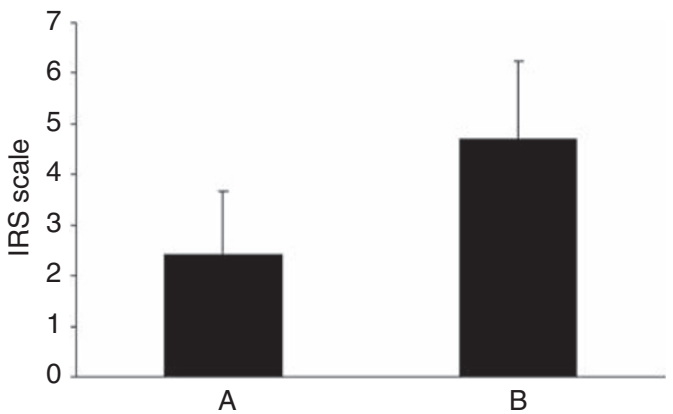

Figure 4 UGT8 expression (A) in node-negative invasive ductal carcinomas $(n=22)$ and (B) node-positive invasive ductal carcinomas $(n=18) . \quad P<0.05$ for UGT8-expressing, node-negative primary breast tumours as compared with node-positive primary tumours (MannWhitney U-test). Reaction intensities with rabbit polyclonal antibodies for UGT8 were calculated on the basis of the semi-quantitative IRS scale of Remmele and Stegner (1987) and are represented as means.

T47D, SKBR-3, BT-474, MCF10CA1a.cl1, MDA-MB-231, and BO2. Western blot analysis showed that high UGT8 expression was limited to the metastasising MCF10CA1a.cl1, MDA-MB-231, and
A

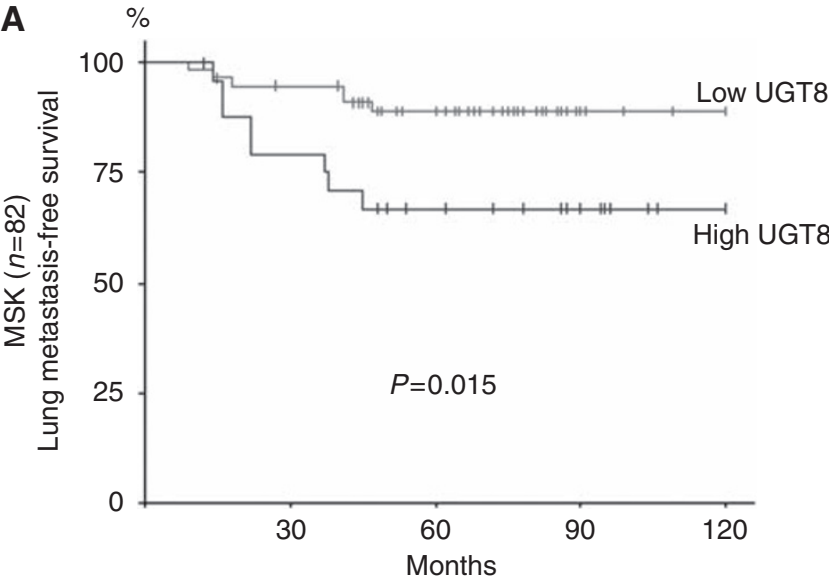

B
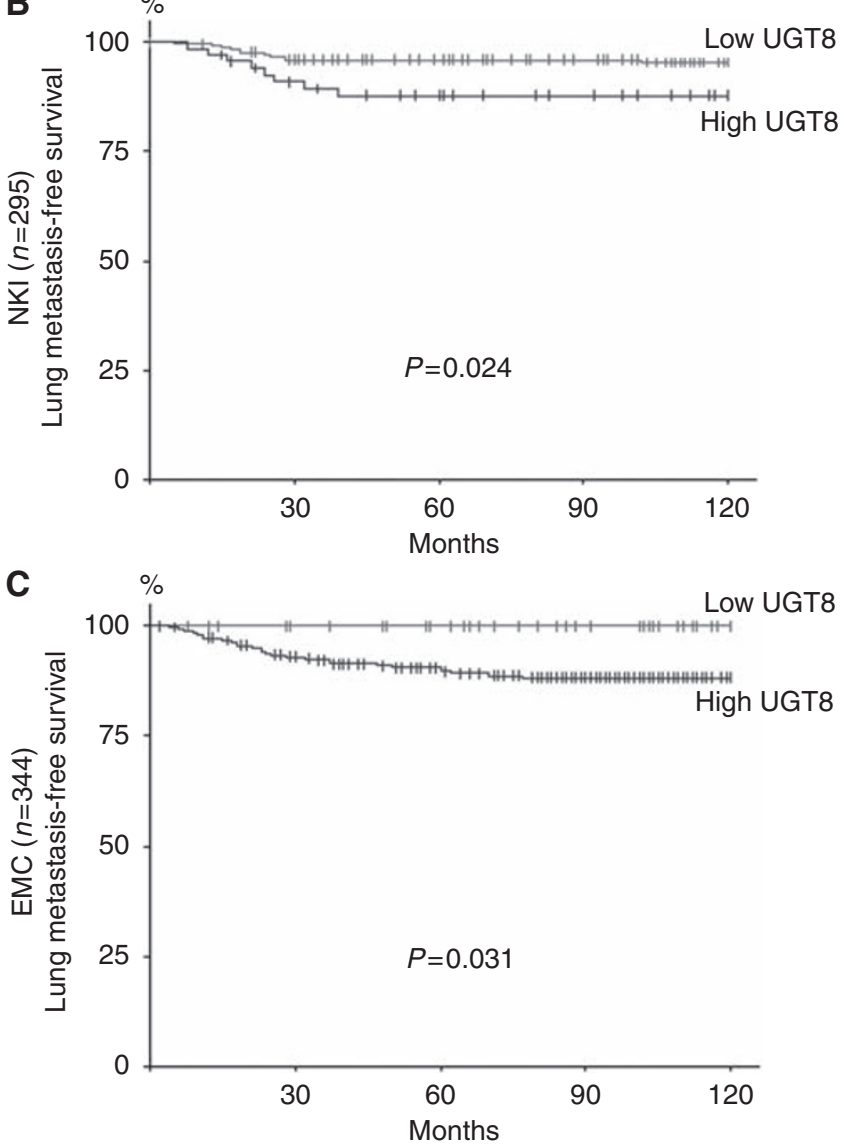

Figure 5 Validation of UGT8 expression as a predictive marker of lung metastasis in three independent series of breast cancer patients. Lung metastasis-free survival was analysed for $(\mathbf{A}) \mathrm{MSK}(n=82)$, (B) NK $(n=295)$, and $(\mathbf{C})$ EMC $(n=344)$. Kaplan-Meier analysis distinguished patients who expressed high levels (high-risk group) and low levels (lowrisk group) of UGT8. Patients with high expression of UGT8 had a shorter lung metastasis-free survival.

BO2 cells (Figure 6A), and no binding was observed for the rest of the analysed cells. These results were confirmed by real-time PCR (Figure 6B) and immunohistochemical staining with anti-UGT8 polyclonal antibodies (data not shown).

\section{Detection of GalCer in established breast cancer cell lines}

Neutral glycolipids purified from the breast cancer cell lines were separated on HP-TLC plates and immunostained with rabbit polyclonal 
A
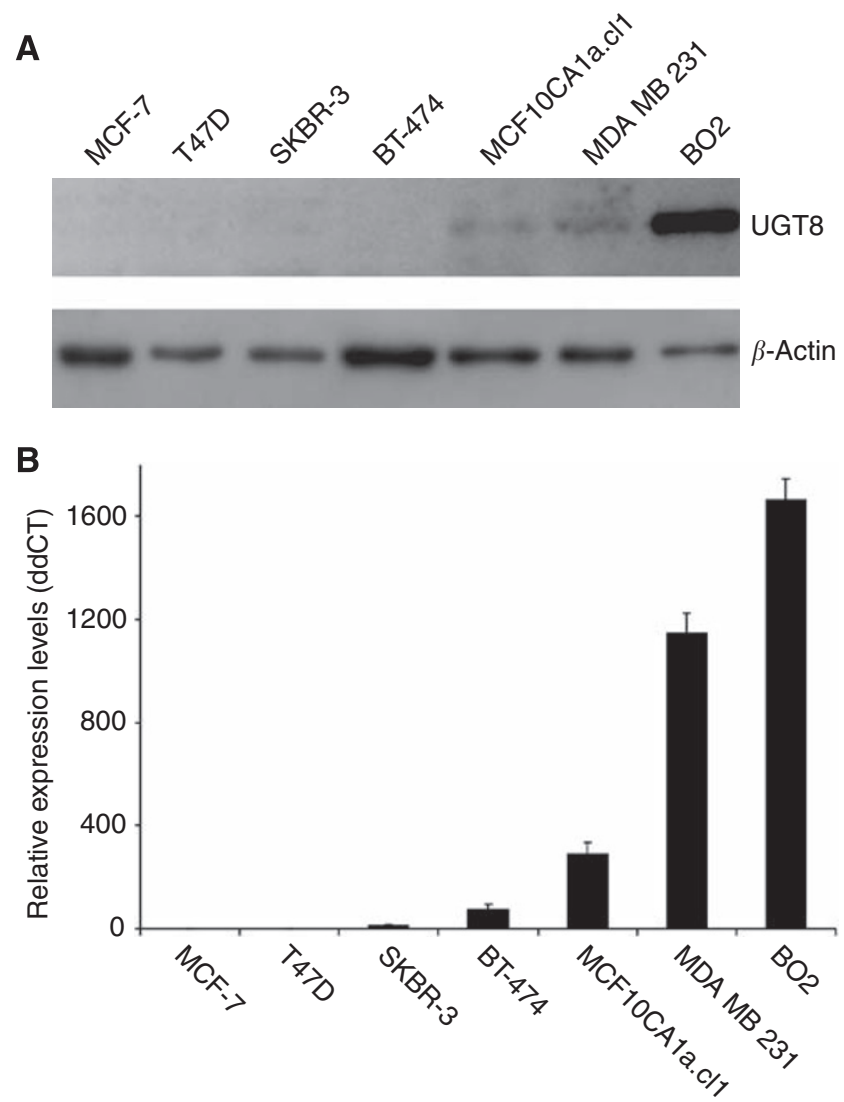

Cell line

Figure 6 (A) Western blot analysis of anti-UGT8 rabbit polyclonal antibodies binding to cellular proteins of breast cancer cell lines. Cell lysates, equivalent to $15 \mu \mathrm{g}$ of protein, were separated by SDS-PAGE under reducing conditions on an $8 \%$ gel and electrophoretically transferred onto a nitrocellulose membrane. $\beta$-Actin served as an internal control. (B) Expression of UGT8 mRNA in breast cancer cell lines. Real-time RT-PCR was used to analyse UGT8 mRNA. UGT8 levels were normalised against GAPDH and cell line MCF-7 was assigned as a calibrator sample. Results are expressed as means.

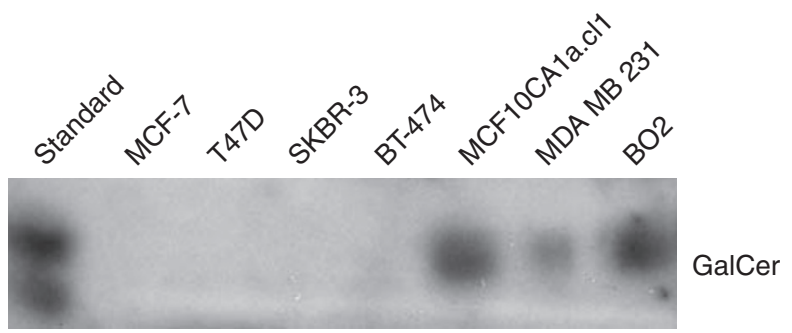

Figure 7 Immunostaining of neutral glycolipids from human breast cancer cell lines, separated by HP-TLC, with anti-GalCer rabbit polyclonal antibodies. For the analysed cell lines, an aliquot of total neutral glycolipids corresponding to $1 \times 10^{7}$ cells was applied to the HP-TLC plate.

antibodies directed against GalCer. Staining of GalCer, migrating as bands of appropriate mobility, was seen only in neutral glycolipid fractions isolated from metastasising breast cancer MCF10CA1a.cl1, MDA-MB-231, and BO2 cells (Figure 7). No bands were detected when using neutral glycolipids isolated from the rest of the analysed cell lines (BT474, SKBR-3, T47D, and MCF-7).

\section{DISCUSSION}

Breast carcinoma is the leading cause of mortality due to malignancy in Europe and North America. Death from breast cancer is mainly due to distant metastases, which are organspecific and localise to bones, liver, lung, and brain (Fidler, 2003). On the basis of transcriptome analysis of primary tumours and distant metastases using genome-wide microarray techniques, it was proposed that the risk for developing metastases can be predicted by a 'metastatic-gene signature' expressed by subsets of primary tumours (van't Veer et al, 2002; Ramaswamy et al, 2003; Weigelt et al, 2003; Driouch et al, 2007). With the use of a nude mice model it was further shown that clones of MDA-MB-231 breast cancer cells developing organ-specific metastases in bone or lung are characterised by the expression of specific subsets of nonoverlapping genes (Kang et al, 2003; Minn et al, 2005a,b). This finding suggested the existence of specific gene signatures determining the localisation of metastases in specific organs, which was confirmed in three independent series of breast tumours showing that the 'lung metastasis signature' is predictive of high risk for the development of lung metastases (Minn et al, 2005a, b, 2007). Recently, a six-gene signature predicting breast cancer lung metastases obtained for metastatic human tissue specimens was published (Landemaine et al, 2008), which correlated with increased risk of lung metastasis in a series of 72 lymph node-negative breast tumours. These data were further validated on a larger series of samples (Driouch et al, 2009).

Among six genes highly overexpressed in lung metastases as compared with that in other breast cancer metastases, UGT8, which encodes an enzyme responsible for the synthesis of galactosylceramide, was found (Landemaine et al, 2008). In other studies on breast cancer, it was shown that elevated expression of UGT8 was significantly associated with ER-negativity and therefore with a more malignant phenotype (Yang et al, 2006; Ruckhäberle et al, 2008). These studies indicating an elevated level of UGT8 in more malignant breast cancer cells were performed only at the level of mRNA expression using microarray analysis and quantitative RT-PCR. In our study we evaluated UGT8 protein expression in primary breast cancer tumours and their matched lung metastases using IHC. Significantly stronger staining with rabbit polyclonal antibodies directed against UGT8 was observed in the specimens from lung metastases than in paired primary tumours, confirming earlier results obtained at the mRNA level. These data suggested that UGT8 is associated in some way with tumour progression, and that its elevated level could be important in the development of lung metastases (see below). Therefore, to study the changes in UGT8 expression during increasing malignancy of breast cancer cells in more detail, samples of breast tumours having different malignancy grades were analysed for the presence of UGT8 at the protein as well as mRNA level. It was found that the amounts of UGT8 protein and mRNA increased with tumour malignancy grades, and highly significant differences in UGT8 expression were found in G3 tumours vs G2 tumours. Interestingly, highly increased expression of UGT8 was also observed in primary node-positive tumours as compared with that in node-negative primary tumours. When the predictive value of UGT8 expression was further analysed at the mRNA level in primary tumours of the 721 breast cancer patients of the three independent cohorts, the patients assigned to the high-risk group had significantly shorter lung metastasis-free survival. Therefore, our data suggest that UGT8 is a significant index of tumour aggressiveness and potential marker for the prognostic evaluation of lung metastases in breast cancer.

According to Lacroix and Leclercq (2004) breast cancer cell lines can be classified into three groups on the basis of their phenotype and invasiveness. The first group, including BT-483, MCF-7, T-47D, and ZR-75 cells, was named 'luminal epithelial-like' because the cells highly express such genes as ER, CDH1 (E-cadherin), TJP1 (zonula occludens-1), and DSP (desmoplakinI/II), typical of the epithelial phenotype of breast cells. All these cells are weakly invasive. The second group, called 'weakly luminal epithelial-like', represented by SKBR-3 cells and BT-474, is similar 
to the first group, expressing the same epithelial markers, although at lower levels. The cells belonging to the third group are quite different as they express proteins found in mesenchymal cells, for example vimentin, and are highly invasive in vitro. They were named 'mesenchymal-like' ('stromal-like') and are represented by MDA-MB-231 and MCF10CA1a.cl1 cells. As the first two groups probably correspond to tumours of grades G1 and G2, and the 'mesenchymal-like' group could represent G3 tumours, we analysed the expression of UGT8 in different breast cancer cell lines. Expression of UGT8 at the mRNA and protein level in the established breast cancer cell lines correlated well with the results obtained for the clinical samples. Cells with the luminal epitheliallike' phenotype (MCF-7, T47D, SKBR-3, and BT-474) did not express or weakly expressed UGT8, in contrast to the malignant, 'mesenchymal-like' cells (MCF10CA1a.cl1, MDA-MB-231, and $\mathrm{BO} 2$ ) forming metastases in the nude mice model.

UGT8 is responsible for the synthesis of galactosylceramide, which is the major glycosphingolipid of myelin in the CNS and peripheral nervous system (Marcus and Popko, 2002). There is very little information available on GalCer expression in human tumours, except for human astrocytomas and oligodendrogliomas (Sung et al, 1996; Popko et al, 2002). Very little is also known about the possible functions of GalCer in tumour cells, which is in striking contrast to glucosylceramide (GlcCer), the other simple glycosphingolipid consisting only of ceramide and glucose residue. It is widely accepted that GlcCer is a mitogenic molecule, as stimulation of its synthesis decreases the intracellular pool of ceramide, which has an important function in programmed cell death as a proapoptotic agent (Radin, 2001; Taha et al, 2006). Interestingly, several lines of evidence suggest that overexpression of glucosylceramide synthase and accumulation of GlcCer can lead to the development of drug resistance in cancer cells (Lavie et al, 1996; Okazaki et al, 1998; Radin, 2001). Therefore we analysed the presence of GalCer in breast cancer cells and found that the 'mesenchymal-like' cells MDA-MB-231, BO2, and MCF10CA1a.cl1, each forming metastases in nude mice, are the only cell lines synthesising this glycolipid. This finding is in agreement with the hypothesis of Beier and Gorogh (2005), who proposed that accumulation of GalCer in tumour cells inhibits apoptosis, which facilitates metastatic cells to survive in the hostile microenvironment of the target organ. However, further functional studies are necessary to confirm this hypothesis.

In summary, we have shown for the first time that (1) expression of UGT8 is higher in breast cancer metastases to the lung than in matched primary tumours and that increased amounts of this enzyme in cancerous tissue are associated with progression to a more malignant phenotype, and (2) expression of UGT8 and GalCer is limited only to breast cancer cell lines forming metastases in a nude mice model.

\section{ACKNOWLEDGEMENTS}

Grant support: Ministry of Science and Higher Education (Poland) (no. 401N 097936) and European Commission Framework Programme VI MetaBre (CEE LSHC-CT-2004-503049).

\section{REFERENCES}

Ariga T, Ando S, Takahashi A, Miyatake T (1980) Gangliosides and neutral glycolipids of human adrenal medulla. Biochim Biophys Acta 618: $480-485$

Beier UH, Gorogh T (2005) Implications of galactocerebrosidase and galactocerebroside metabolism in cancer cells. Int J Cancer 115: 6-10

Bosio A, Binczek E, Stoffel W (1996) Functional break-down of the lipid bilayer of the myelin membrane in central and peripheral nervous system by disrupted galactosylcerebroside synthesis. Proc Natl Acad Sci USA 93: $13280-13285$

Bouhours JF, Bouhours D (1979) Galactosyloceramide is the major cerebroside of human milk fat globule membrane. Biochem Biophys Res Commun 88: 1217-1222

Coetzee T, Fujita N, Dupree J, Shi R, Blight A, Suzuki KI, Suzuki KU, Popko B (1996) Myelination in the absence of galactosylcerebroside and sulfatide: normal structure with abnormal function and regional instability. Cell 86: 209-219

Driouch K, Landemaine T, Sin S, Wang S, Lidereau R (2007) Gene arrays for diagnosis and treatment of breast cancer metastasis. Clin Exp Metastasis 24: $575-585$

Dupree JL, Girault J, Popko B (1999) Axo-glial interactions regulate the localization of axonal paranodal proteins. I Cell Biol 147: 1145-1151

Driouch K, Bonin F, Sin S, Clairac G, Lidereau R (2009) A six-gene signature predicting breast cancer lung metastasis. Reply Cancer Res 69: 9507 - 9511

Dyer CA, Benjamins JA (1990) Glycolipids and transmembrane signaling: antibodies to galactocerebroside cause an influx of calcium in oligodendrocytes. J Cell Biol 111: 625-633

Dyer CA, Benjamins JA (1991) Galactocerebroside and sulfatide independently mediate $\mathrm{Ca}^{2+}$ responses in oligodendrocytes. J Neurosci Res 30: $699-711$

Elston CW, Ellis IO (1991) Pathological prognostic factors in breast cancer: experience from a large study with long-term follow-up. Histopathology 19: $403-410$

Fidler IJ (2003) The pathogenesis of cancer metastasis: the 'seed and soil' hypothesis revisited. Nat Rev Cancer 3: 453-458

Hakomori S (1996) Tumor malignancy defined by aberrant glycosylation and sphingo(glyco)lipid metabolism. Cancer Res 56: 5309-5318

Hakomori S, Murakami WT (1968) Glycolipids of hamster fibroblasts and derived malignant-transformed cell lines. Proc Natl Acad Sci USA 59: $254-261$

Kang Y, Siegel PM, Shu W, Drobnjak M, Kakonen SM, Cardon-Cardo C, Guise TA, Massague J (2003) A multigenic program mediating breast cancer metastasis to bone. Cancer Cell 3: 537-549

Kapitonov D, Yu RK (1997) Cloning, characterization, and expression of human ceramide galactosyltransferase cDNA. Biochem Biophys Res Commun 232: $449-453$

Kodama S, Igisu H, Siegel D, Suzuki K (1982) Glycosylceramide synthesis in the developing spinal cord and kidney of the twitcher mouse, an enzymatically authentic model of human Krabbe disease. J Neurochem 39: $1314-1318$

Lacroix M, Leclercq G (2004) Relevance of breast cancer cell lines as models for breast tumors: an update. Breast Cancer Res Treat 83: 249-289

Landemaine T, Jackson A, Bellahcene A, Rucci N, Sin S, Abad BM, Sierra A, Boudinet A, Guinebretiere JM, Ricevuto E, Nogues C, Briffod M, Bieche I, Cherel P, Castronovo V, Teti A, Lidereau R, Driouch K (2008) A six-gene signature predicting breast cancer lung metastasis. Cancer Res 68: 6092-6099

Lavie Y, Cao H, Bursten SL, Giuliano AE, Cabot MC (1996) Accumulation of glucosylceramides in multidrug-resistant cancer cells. J Biol Chem 271 $19530-19536$

Magnani JL, Nilsson B, Brockhaus M, Zopf D, Stęplewski Z, Koprowski H, Ginsburg V (1982) A monoclonal antibody defined antigen associated with gastrointestinal cancer is a ganglioside containing sialylated lacto$N$-fucopentaose II. J Biol Chem 257: $14365-14369$

Minn AJ, Gupta GP, Padua D, Bos P, Nguyen DX, Nuyten D, Kreike B, Zhang Y, Wang Y, Ishwaran H, Foekens JA, van de Vijver M, Massague (2007) Lung metastasis genes couple breast tumor size and metastatic spread. Proc Natl Acad Sci USA 104: 6740-6745

Minn AJ, Gupta GP, Siegel PM, Bos PD, Shu W, Giri DD, Viale A, Olshen AB, Gerald WL, Massague J (2005a) Genes that mediate breast cancer metastasis to lung. Nature 436: 518-524

Minn AJ, Kang Y, Serganowa I, Gupta GP, Giri DD, Doubrovin M, Ponomarev V, Gerald WL, Blasberg R, Massague J (2005b) Distinct organ-specific metastatic potential of individual breast cancer cells and primary tumors. J Clin Invest 115: 44-55

Marcus J, Popko B (2002) Galactolipids are molecular determinants of myelin development and axo-glial organization. Biochim Biophys Acta 1573: $406-413$

Natomi H, Saitoh T, Sugano K, Iwamori M, Tukayama M, Nagai Y (1993) Systemiatic analysis of glycosphingolipids in the human gastrointestinal 
tract: enrichment of sulfatides with hydroxylated longer-chain fatty acids in the gastric and duodenal mucosa. Lipids 28: 737-742

Nilsson O, Svennerholm L (1982) Characterization and quantitative determination of ganglioside and neutral glycosphingolipids in human liver. J Lipid Res 23: 327-334

Ogawa K, Fujiwara Y, Sugamata K, Abe T (1988) Thin-layer chromatography of neutral glycosphingolipids: an improved simple method for the resolution of GlcCer, LacCer and $\mathrm{Ga}_{2}$ Cer. J Chromatogr 426: $188-193$

Okazaki T, Kondo T, Kitano T, Tashima M (1998) Diversity and complexity of ceramide signaling in apoptosis. Cell Signal 10: 685-692

Oudes AJ, Roach JC, Walashek L, Eichner LJ, True LD, Vessella RL, Liu AY (2005) Application of affymetrix array and massively parallel signature sequencing for identification of genes involved in prostate cancer progression. BMC Cancer 5: 86

Pfeiffer SE, Warrington AE, Bansal R (1993) The oligodendrocyte and its many cellular processes. Trends Cell Biol 3: 191-197

Popko B, Pearl DK, Walker DM, Comas TC, Baerwald KD, Burger PC, Scheithauer BW, Yates AJ (2002) Molecular markers that identify human astrocytomas and oligodendrogliomas. J Neuropathol Exp Neurol 61: 329-338

Radin NS (2001) Killing cancer cells by poly-drug elevation of ceramide levels: a hypotheis whose time has come? Eur J Biochem 268: 193-204

Ramaswamy S, Ross KN, Lander ES, Golub TR (2003) A molecular signature of metastasis in primary solid tumors. Nat Genet 33: 49-54

Remmele W, Stegner HE (1987) Vorschlag zur einheitlichen Definition eines immunreactivn Score (IRS) fuer den immunohistochemischen Ostrogenrezeptor-Nachweis (ER-ICA) im Mammakarzinomgewebe. Pathologe 8: 138-140

Ruckhäberle E, Rody A, Engels K, Gaetje R, von Minckwitz G, Schiffmann S, Grösch S, Geisslinger G, Holtrich U, Karn T, Kaufmann M (2008) Microarray analysis of altered sphingolipid metabolism reveals prognostic significance of sphingosine kinase 1 in breast cancer. Breast Cancer Res Treat 112: 41-52

Schulte S, Stoffel W (1993) Ceramide UDP galactosyltransferase from myelinating rat brain: purification, cloning and expression. Proc Natl Acad Sci USA 90: 10265-10269

Sprong H, Kruithof B, Leijendekker R, Slot JW, van Meer G, van der Sluijs P (1998) UDP-galactose:ceramide galactosyltransferase is a class I integral membrane protein of the endoplasmic reticulum. I Biol Chem 273: $25880-25888$

Sung CC, Collins R, Li J, Pearl DK, Coons SW, Scheithauer BW, Johnson PC, Yates AJ (1996) Glycolipid and myelin proteins in human oligodendrogliomas. Glycoconj J 13: 433-443

Taha TA, Mullen TD, Obeid LM (2006) A house divided: ceramide, sphingosine, and sphingosine-1-phosphate in programmed cell death. Biochim Biophys Acta 1758: 2027-2036

Ugorski M, Pahlsson P, oelig; D, Nilsson B, Radzikowski C (1989) Glycosphingolipids of human urothelial cell lines with different grades of transformation. Glycoconj J 6: 303-318

van't Veer LJ, Dai H, van de Vijver MJ, He YD, Hart AA, Mao M, Peterse HL, van der Kooy K, Marton MJ, Witteveen AT, Schreiber GJ, Kerkhoven RM, Roberts C, Linsley PS, Bernards R, Friend SH (2002) Gene expression profiling predicts clinical outcome of breast cancer. Nature 415: $530-536$

van de Vijver MJ, He YD, van't Veer LJ, Dai H, Hart AA, Voskuil DW, Schraiber GJ, Peterse JL, Roberts C, Marton MJ, Parrish M, Atsma D, Witteveen A, Glas A, Delahaye L, van der Velde T, Bartelink H, Rodenhuis S, Rutgers ET, Friend SH, Bernards R (2002) A geneexpression signature as a predictor of survival in breast cancer. $N$ Engl J Med 347: 1999-2009

Vos JP, Lopes-Cardozo M, Gadella BM (1994) Metabolic and functional aspects of sulfogalactolipids. Biochim Biophys Acta 1211: $125-149$

Wang Y, Klijn JG, Zhang Y, Sieuwerts AM, Look MP, Yang F, Talantov D, Timmermans M, Meijer-van Gelder ME, Jatkoe T, Berns EM, Atkins D, Foekens JA (2005) Gene-expression profiles to predict distant metastasis of lymph-node-negative primary breast cancer. Lancet 365: $671-679$

Weigelt B, Glas AM, Wessels LF, Witteveen AT, Peterse JL, van't Veer LJ (2003) Gene expression profiles of primary breast tumors maintained in distant metastases. Proc Natl Acad Sci USA 100: 15901-15905

Yang F, Foekens JA, Yu J, Sieuwerts AM, Timmermans M, Klijn JG, Atkins D, Wang Y, Jiang Y (2006) Laser microdissection and microarray analysis of breast tumors reveal ER-alpha related genes and pathways. Oncogene 25: $1413-1419$ 